\title{
Implementation of Interactive Maps for Student Learning Outcomes
}

\author{
Eni Heldayani ${ }^{1 *}$, Maharani Oktavia ${ }^{1}$, Siti Asiyah ${ }^{1}$ \\ ${ }^{1}$ University of PGRI Palembang \\ *Corresponding author.Email: eniheldayani@univpgri-palembang.ac.id
}

\begin{abstract}
Effective learning media can certainly have an impact on the success of learning outcomes. The aim of this paper to find out the implementation of interactive maps for student learning outcomes. The research design is an experiment method with a non-probability sampling type purposive sampling technique. There are two selected groups as sampling, Social Class 1 with 38 students as an experiment and Social Class 2 with 38 students as a control. The results showed the implementation of an interactive map for student learning outcomes, from the testing of hypothesis showed that $\mathrm{t}$ count $=9.43$ and $t$ table $=1.66$, then we accept the alternative hypothesis and rejected the null hypothesis. Thus, the implementation of an interactive map can improve student learning outcomes.
\end{abstract}

Keywords: Interactive maps, Learning outcomes, Social classes

\section{INTRODUCTION}

The goals of increasing the human quality resources beyond education are related to any aspects, one of them concerns the teacher creativity to design learning resources [1]. The problems that often find out are inadequate learning media such as availability and utilization [2].

The learning media can present the learning process significantly. The obscurity in the learning process can be resolved by presenting the media as a supporting tool [3]. The imperfections of the learning material to be conveyed to students are simpler through the media. Learning media is an alternative to cover up the weaknesses of teachers who are too dominant in speaking when delivering material in class [4]. The clarity of the learning material can be made real through the media. Thus, students understand more easily the learning material than without the media [5].

The teaching and learning process that uses media can have an impact on interest, motivation, stimulate learning activities, and influence student behavior. The implementation of learning media accompanied by the delivery of learning material content at the beginning of the learning activity greatly helps the learning process and outcomes [6]

Geography is teaching about geographical symptoms that are spread on the surface of the earth to provide students with an image of the distribution and location of symptoms [7]. The main purpose of learning geography is to habituate students to think spatially as attached in the core competence of geography materials.
Geography learning can be carried out by various methods such as lectures, question and answer, and discussion. Geography learning will be more effective when using a teaching aid or by showing it on media. This is several research results that state that learning outcomes will be much better if learning media are used appropriately and well.

Teachers can generally take advantage of several media in geography learning [8] such as maps, atlases, globes, pictures, diagrams, charts, portraits, slides, films, printed media in the form of newspapers and magazines that are used to show and demonstrate related material in geography learning. Interactive maps is a concept (round earth on the flat paper) and the basic essence of geography. Therefore, teaching geography without maps will not form good images and concepts in students that can improve their cognitive, affective, and psychomotor. Interactive learning media can make the process of learning more interactive so that learning objectives will be achieved as desired. One of the interactive learning media is map media.

A map is a two-dimensional tool from the surface of the earth that provides information regarding the state of the earth's surface, place and direction, and distance from other places [9]. A collection of maps in the form of a book is called an atlas, from the use of atlases it can form correct concepts in students regarding the nets of degrees, legends, indexes, etc. Globes are a very mini model and shape of the globe, with the use of a globe it can form the correct images and concepts in students regarding time, climate, seasons, and other natural phenomena. Images are visual representations of people, places, or objects 
that are embodied in canvas, paper, or other materials, either through paintings, pictures, and photographs.

Competency Standards are used in the learning process [10], namely Understanding the basics of mapping. The indicators used are as follows: 1) Describe the meaning of the map from several figures; 2) Describe the functions of the map; 3) Describe the types of maps from media sources; 4) Describe the map elements from media sources; 5) Distinguish map types from media sources. The interactive map can be used to help the teachers in giving lessons to students. The use of maps or the art of cartography can improve students' spatial abilities, such as providing learning activities in the form of guided activity practices by utilizing aerial photography as a fun learning medium, through this practical activity students are invited to visualize and interpret aerial photographs and map symbolization [11]

The use of map media helps students understand the subject matter presented, however, is it true that by using interactive maps as media, high school students 'geography learning outcomes will be better, or is it the opposite, using map media, students' learning outcomes of geography subjects will decrease.

\section{METHODS}

The research was conducted at SMA Negeri 9 Palembang. The research design is an experiment method with a non-probability sampling type purposive sampling technique. There are two selected groups as sampling, Social Class 1 with 38 students as an experiment and Social Class 2 with 38 students as a control.

To collect the required data for student learning outcomes using tests given in writing, in multiple-choice questions as many as 30 questions after the material has been taught (post-test) using interactive maps. The normality of the experiment class data from the calculation of the slope of the curve using the Karl Pearson formula, the value of $\mathrm{Km}$ was obtained at -0.64 , this price is between $(-1)$ and $(+1)$, so the test data in the experiment class can be concluded to be normally distributed. While the control class calculation is rated as $\mathrm{Km}-0.010$ and because the $\mathrm{Km}$ value is -0.054 this price lies between (-1) and (1), the control class data were normally distributed.

The final part after proving the hypothesis was summary. If Ho is rejected, so there are a significant difference in the ability of student learning outcomes before and after using interactive maps. Otherwise, if Ho is accepted it means there is no difference.

\section{RESULTS AND DISCUSSION}

The test was given to students who were the sample in this study using a comparison between two classes, namely social class 1 as the experiment and social class 2 as the control. Researchers give tests to students after the subject matter has been discussed. The technique used in collecting data about student learning outcomes is a test technique in the form of multiple-choice questions totaling 30 items, according to the subject matter that has been discussed.

The test results of social class 1 student as an experiment class using an interactive map on average 87,7 and students in social class 2 as the control class 63,72 . The results showed that the learning outcomes of the experiment class which using the interactive maps were better than student at control class who were taught without it. There are differences in the scores obtained from the experiment class and the control class, the cause of the low scores obtained by students in the control class is because the learning process uses lecture learning and question and answer learning which makes learning more teacher-oriented so that students are less active in the student learning process.

The research stage in the experiment class and control class was carried out three times. In the second and third first meetings before giving the test, the researcher explained the material about the map by implementing learning using interactive maps in the experiment class and the lecture method in the control class.

After the learning process is complete, a post-test is given to the student. The learning outcomes of the experiment class are better than the control class. This can be seen from the average value of the experiment class using interactive maps, the highest score is 97 and the lowest is 82 and the experiment class average value is 87,7 . For the control class, the highest score was 81 and the lowest score was 49 and the mean score for the control class was 63,72 . From the results of the analysis, it can be seen that the learning outcomes of the experiment class which were treated using maps was better than the control class.

To test the distribution of data that is normally distributed or not, the data normality test is used. The calculation of the data normality test uses the Karl Pearson formula which results that the sample class is normally distributed if the $\mathrm{Km}$ value is between $(-1)$ and $(+1)$. In the experiment class, the $\mathrm{Km}$ value is -0.64 , this price is located between $(-1)$ and $(+1)$, while for the control class, the $\mathrm{Km}$ value is -0.064 is located between $(-1)$ and $(+1)$, then the test result data in the experiment and control class it can be concluded that the distribution is normal. Then after the data were normally distributed, the data homogeneity test was carried out, the Bartlett test results obtained X2 count of -72.38 and X2 table of 3.84 . Data can be said to be homogeneous if $\mathrm{X} 2$ count $<\mathrm{X} 2$ table, from the results of the data analysis above it, can be concluded that $-72.38<3.84$ so that the data is homogeneous.

After testing for normality and homogeneity and the data can be said to be normally distributed and homogeneous, then hypothesis testing is done using the $\mathrm{t}$-test with the test criteria accepting $\mathrm{Ha}$ if $\mathrm{t}$ count $>\mathrm{t}$ table and rejecting $\mathrm{Ha}$ if $\mathrm{t}$ count $<\mathrm{t}$ table. From the results of data analysis, the value of $t$ count $=9.43$ while $t$ table $=$ 
1.66, based on the hypothesis testing criteria, $\mathrm{Ha}$ is accepted and $\mathrm{HO}$ is rejected. Thus, the results of the calculation of the analysis of the experiment class that was treated using interactive maps showed an influence and an increase in the student learning outcomes compared to the control class. Besides, the research hypothesis testing was carried out using a simple linear regression formula and obtained $\mathrm{Y}=71.29+10.64 \mathrm{X}$. This equation means that there is a functional relationship between the independent variable and the dependent variable, while the level of relationship of each variable using the product-moment correlation formula is obtained r_xy $=0.588$, which means the level of relationship between the independent and dependent variables. variable height. Therefore, it can be concluded that there is a positive effect of interactive maps on the spatial abilities of social class students.

\section{CONCLUSION}

Effective learning media can certainly have an impact on the success of learning outcomes. The aim of this paper to find out the implementation of interactive maps for student learning outcomes. The results showed the implementation of an interactive map for student learning outcomes, from the testing of hypothesis showed that $\mathrm{t}$ count $=9.43$ and $\mathrm{t}$ table $=1.66$, then we accept the alternative hypothesis and rejected the null hypothesis. Thus, the implementation of an interactive map can improve student learning outcomes.

\section{ACKNOWLEDGMENT}

This paper is one of the research outputs which supported/partially supported by Universitas PGRI Palembang, Associate Lecturer Research Grant 2020. We also thank our colleagues from The Geography Department, Faculty of Teacher Training and Education.

\section{REFERENCES}

[1] Huynh, N. T., \& B. Sharpe. (2009). The role of geospatial thinking in effective GIS problem solving: K-16 educa- tion levels. Geomatica 63 (2): 119-128

[2] National Research Council. (2006). Learning to Think Spatially: GIS as a Support System in The K12 Curriculum (Washongton, DC. National Academies Press).

[3] Siagian, S. (2012). Pengembangan Media Pembelajaran Interaktif pada Mata Pelajaran Geografi [Development of Interactive Learning Media on Geography Subjects]. Jurnal Teknologi Pendidikan, 5 (1). pp. 22-30. ISSN 1979-6692

[4] Bahri, S., \& Zain, A. (2002). Strategi Belajar Mengajar [Teaching and Learning Strategies]. Jakarta: Rineka Cipta.
[5] Falahudin, I. (2014). Jurnal Lingkar Widyaiswara. Edisi 1 No.4

[6] Sumaatmajda, N. (2001). Metodologi Pengajaran Geografi [Geography Teaching Methodology]. Jakarta: Bumi Aksara.

[7\} Peraturan Menteri Pendidikan Nasional (Permendiknas) Nomor 20 Tahun 2003 tentang Standar Penilaian Pendidikan [Regulation of the Minister of National Education Number 20 of 2003 concerning Education Assessment Standards]. Jakarta: Depdiknas

[8] Umam, K. (2013). Pengaruh Media Peta Rupa Bumi dalam Pembelajaran Geografi terhadap Hasil Belajar Siswa kelas XII IPS MA Islam An-Nidhom Kabupaten Demak [The Effect of Earth Map Media in Geography Learning on Learning Outcomes of Class XII IPS MA Islam An-Nidhom, Demak Regency]. Semarang: Universitas Negeri Semarang.

[9] Utami, S. Q., \& Heldayani, E. (2019). Identifikasi Karakteristik Permukiman Melalui Sistem Informasi Geografi di Kelurahan 1 Ulu, Kecamatan Seberang Ulu 1, Kota Palembang [Identification of Settlement Characteristics through Geographic Information Systems in 1 Ulu Village, Seberang Ulu 1 District, Palembang City]. Jurnal Geografi Gea, Vol 19 No 1.

[10] Asiyah, S. (2020). Pemanfaatan Seni Kartografi untuk Meningkatkan Kemampuan Spasial Siswa SMA Negeri 1 Pemulutan [Utilization of the Art of Cartography to Improve the Spatial Ability of Students of SMA Negeri 1 Pemulutan]. Jurnal Pengabdian Kepada Masyarakat. Volume 26 No. 1, Januari-Maret 2020

[11] Aliman, M. (2020). Pengembangan Instrumen Tes Kemampuan Berpikir Spasial Bagi Siswa SMA [Development of Spatial Thinking Ability Test Instruments for High School Students]. Geodika: Jurnal Kajian Ilmu dan Pendidikan Geografi. Volume 4 Nomor 1 Juni 2020, Halaman: 1-10 